\title{
Moral values found in the album thankyou allah by maher zein
}

\author{
Fitri Windayanti ${ }^{1}$, Tahrun ${ }^{2}$, Mulyadi $^{3}$ \\ ${ }^{1}$ SMP Negeri 3 Jirak Jaya \\ ${ }^{2}$ Universitas PGRI Palembang
}

\begin{tabular}{|c|c|}
\hline Article Info & ABSTRACT \\
\hline Article history: & \multirow{9}{*}{$\begin{array}{l}\text { This study aimed to find out the moral values in the album thank you Allah by } \\
\text { Maher Zein and the theoretical implication for teaching songs and ELT. The } \\
\text { research method used in this study was descriptive qualitative method. The } \\
\text { sources of data were ten song lyrics from Maher Zein album. Method of } \\
\text { collecting the data was triangulation: lyrics, interview, and book review. The } \\
\text { data of this study were analyzed through: listening the songs, reading ten lyrics } \\
\text { from the album, and analyzing the moral values by underlining, defining, } \\
\text { classifying, reanalysing, and coding. The research found ten moral values in } \\
\text { the album were: love and affection, believe, thankfully, forgiveness, loyalty, } \\
\text { togetherness, honesty, bravery, courage and struggle. By analyzing the moral } \\
\text { values, hopefully it could build the good character for us and finally we could } \\
\text { give an inspiration to others. For the theoretical implication, it could be } \\
\text { concluded that moral values could be taught through songs }\end{array}$} \\
\hline Received Jul 12 ${ }^{\text {th }}, 2021$ & \\
\hline Revised Aug $14^{\text {th }}, 2021$ & \\
\hline Accepted Aug 30 $0^{\text {th }}, 2021$ & \\
\hline Keyword: & \\
\hline Album & \\
\hline Maher Zein & \\
\hline Moral Values & \\
\hline Thank You Allah & \\
\hline
\end{tabular}

(C) 2021 The Authors. Published by IICET.

C 2021 The Authors. Published by IICET.
This is an open access article under the CC BY-NC-SA license

CC NC SA (https://creativecommons.org/licenses/by-nc-sa/4.0

\section{Corresponding Author:}

Fitri Windayanti

SMP Negeri 3 Jirak Jaya

Email: angelwinda24@gmail.com

\section{Introduction}

Every human being all over the world interacts with one another through language. There are two meanings of language, as per Sugono, et al. (2008), language is a system of arbitrary and traditional sound symbols that is used as a communication tool to express feelings and ideas, the company concept said. The second definition said that language is the utterance used by the community (ethnicity, country, region, etc.). Based on the above definition, the researcher concludes that language is a sound symbol system that represents human feelings and ideas that are embraced and used as a communication tool by a group of people.

There are many languages in the world, such as national languages, ethnic languages, and even slang languages. English is one of the most common languages used worldwide. As a native speaker of English, there are several countries. [1] that English is a foreign language and the most whispered means of communication, both because of its speaker's number and geographical areas and because of the large number of non-natives who use it for part of their international interaction.

Language is a system of traditional spoken or written symbols that individuals use to communicate with each other. To talk, to connect and to get information from other people, people need language. People will communicate with others through song at this time. Via music, his voice could be conveyed to many people, so that people could understand his feelings. A lot of songs, such as song with the theme of love, social, religion and others, could currently convey our felling. 
Language is described as "a means of communication internationally" [2] It means that language is used as the medium of communication between the speaker and listener while people participate in communication. Language helps the speaker to encrypt messages, enabling the listener to re-decode the message [3]. The speaker and listener can both understand each other through language. Thus, there would be a language if there is contact. So, it is closely linked to language and communication.

Music or song also affects the functioning of the brain, especially for children who can still receive more of their brain memory.

The song is part of literature, as far as we know. Literature is a term derived from the Latin word 'Littera,' which means 'letter of the alphabet,' according to [4], there are several descriptions of literature as a field of study. Some of these meanings tend to identify literary writings that are valued as artistic works, a country's literature, or something in print. Generally, in the lyrics, each writer has plenty of creativity. There are several concepts in the post, such as liberalism, humor, praise, inspiration, education, and romance.

Literature is also one of the media that displays certain importance, one of which is the moral meaning that the author provides. The author aims to teach and deliver good morals to people through songs, poems, movies or other literary works. People have to boost their good morale and sustain it. It is a common word to say morality, but it is very difficult to suggest it in the everyday life of humans.

Moral values, particularly as adolescents as students, are now very forgotten. Since many students do something out of control. For this purpose, students need more guidance on moral principles. And that is one of the reasons why this subject is selected by the author. Moral principles are a significant law for human beings, [5], Emotion, self-control, inspiration, compassion, obligation, integrity, commitment, duty, empathy, and the promotion of respect for the reality are moral values. Morality and value not only drive the production of inspiration, but also the encouragement and energy to live and do something meaningful.

Morality is about the goodness or badness of character or disposition, or about the contrast between right and wrong. An person is said to have good or poor character or behaviour, to be virtuous according to civilized principles of right or wrong, to be able to understand right or wrong. Moreover, it can be said that morality is the effort to obtain a comprehensive understanding of the meaning of morality and what is expected of how individuals have to comply with the norm of life as a capable moral standard in society.

There are many solo singers or band members in the music industry. Maher Zein is one of the solo singers. With his meaningful values, he is a star of modern Islamic music with songs that seek to encourage and entertain people and give the world a message of peace and hope. He's got lots of famous songs and he's got two albums now, Thank You Allah and Forgive Me. Two albums are published by Maher Zein, both of which are well known worldwide because each song has several words that have the power to affect people. In his songs, he often portrays universal values or a message.

It is really important to do a review on the moral meaning of song lyrics from the debate above. Therefore, the writer take the title of the study as "Moral Values Found In The Album Thank You Allah By Maher Zein'"

\section{Method}

This study used a descriptive qualitative approach since, through the song lyrics of Maher Zein, the researcher wanted to examine the moral meaning in the album thank you Allah. The writer used descriptive qualitative because the purpose of descriptive research is to describe a phenomenon and its characteristics, as described [6].Songs from the album Thank You Allah by Maher Zein released in 2009 were the data sources of this study. Document study is acquiring a case, book, transcript video, magazine or newspaper details [7].The writer required a certain method to collect the data. The measures were: the writer found the data from the album entitled Thank You Allah by Maher Zein. The details in this study was the album's song lyrics. After the writer determined the acceptable and incorrect details after collecting the data, the writer listed them on the album song. The writer classified the entire database on the kinds of moral value after making a list of details. The data were analyzed through listening the songs, reading ten lyrics from the album, and analyzing the moral values by underlining, defining, classifying, reanalysing, and coding.

\section{Results and Discussions}

The conclusions of this study were about moral principles found in Maher Zein's album Thank You Allah and the theoretical consequences for English Language Teaching. 


\section{Moral Values of Album Thank You Allah}

\section{Love and Affection}

Love is the term for the letter in the communication code. Love is a reference to God's worship [8]. This is Affection is an act influenced by affection or circumstances. Affection is a kind, tender connection that falls: love, good, will. Affection (as rage, fear or hatred) is powerful emotion or passion; feeling or natural instinct swaying the mind: inclination and disposition [8]. Love and affection should be expected in society. Humans need to love each other. This is done to eliminate confrontation and disunity. Moreover, love and affection have the function of sustaining a daily life of harmony.

One of the most profound feelings that we feel as humans is passion. However, love is a step beyond love. It is one that leads to emotions of closeness, passion and comfort. For our wife, family, siblings, neighbors or friends, we have love and affection.

The writer found two songs from ten songs examined by the writer that contained moral meaning, passion and affection. There are: For the rest of my life and Number one for me.

1) The fifth song "For The Rest Of My Life"

* S.5. St.2 LA : I'll be loving you, loving you

There is the word love, then the lyric above was classified as love and affection. The singer assured the listener that, until the end of his life, the singer would always love his wife.

* S.5. St.3 LA : And I Sing it loud that I will love you eternally

The lyric above was classified as love and affection because the singer told the hearer that he needed to persuade his wife and he really loved his wife. He demonstrated that when his wife was there with him, love would be best.

2) The sixth song "Number One For Me"

* S.6. St.3 LA : Now I will try to love you like you love to me

The lyric above was classified as love and affection. The singer tells the listener how much the singer loved his mother. Even if he's naughty when he's a child, his mother always cared for him. He needed to love his mother just as much as his mother loved him.

The writer considered the spiritual significance of love and affection in some lyrics from the data above. There are two lyrics in the fifth song and there is one lyric in the sixth song, the total moral worth of love and affection in the album thank you Allah is three lyrics for the song.

\section{Thankfulness}

1) The first song "Thank You Allah"

* S.1. St.4 Th : Allah, I wanna thank you

The lyric above was classified as thankfulness because the singer tells the hearer that he wanted to say thanks to Allah.

* S.1. St.4 Th : I wanna thank you for all the things that you have done

The lyric above was classified as thankfulness because the singer told the hearer that he wanted to thank you for all kindness that Allah had given to him. Although he lost the way, but God still forgave him. That's why, people must thank to Allah sincerely, by follow all of his commands.

* S.1. St.5 Th : Thank you with every breath I take

The lyric above was classified as thankfulness. The singer told the listener that he had to face everything, even though it was very difficult for him but he believed that God would give the way out to him, and God would give His guidance to mankind's steadfastness and effort.

2) The fourth song "Freedom"

* S.4 St.2 Th : Oh God thank you for giving us the strength to hold on 
The lyric above was classified as thankfulness because the singer told the listener that he thanked to Allah for they could work togetherness and build the unity to fight the oppression.

3) The fifth song "For The Rest Of My Life"

* S.5. St.1 Th : I praise Allah for sending me you my love

The lyric above was classified as thankfulness. The singer told the listener that he thanked to God for giving him a lovely wife for his life.

\section{* S.5. St.2 Th : I'll thank Allah for opening my eyes}

The lyric above was classified as moral value of thankfulness because the singer told the listener that he always thanked to God for giving such a beautiful wife for him who always being by his side.

4) The eighth song "Open Your Eyes"

* S.8. St.5 Th : Forever we thank you, Alhamdulillah

The lyric above was classified as thankfulness because the singer said Alhamdulillah the word came from Arabic which meant thanks to Allah and praise to Allah.

5) The ninth song "So Soon"

* S.9. St.1 Th : I'm so grateful for every moment I spent with you

The lyric above was classified as thankfulness because the singer told the listener that he grateful for every moment with his father or mother and their togetherness was the most beautiful moment.

\section{Loyalty}

Loyalty is the quality of remaining firm for someone or something in your relationship or service. There is moral worth of loyalty from the ten songs that the writer examined, the writer found four songs, there are: Thank you Allah, The Chosen One, For the rest of my life and Number One for me. See the following description.

1) The first song "Thank You Allah"

* S.1. St.5. L : All praises to Allah

The lyric above was classified as thankfulness because the singer told the listener that he always felt grateful to Allah and he shown his loyalty by praising Him. God gave him strength to make him stronger in difficult time. To improve himself, Allah brought him to the right way. Allah was the only one who inspires his life.

2) The third song "The Chosen One"

\section{* S.3. St.5. L : I will try follow your way}

The lyric above was classified as thankfulness because the singer told the listener that he wanted to follow the way of Muhammad S.A.W The lyric above was classified as thankfulness because the singer told the listener that he wanted to follow the way of Muhammad S.A.W because there was no one else like him, and he was God's best creature. The singer conveyed in this song that there was nothing in the world that could characterize the amazing Prophet Muhammad S.A.W.

3) The fifth song "For The Rest Of My Life"

* S.5. St.2. L : I'll stay by your side honest and true

The lyric above was classified as the moral value of loyalty because the singer said in the lyric that he still stayed fair and true with his wife until the end of the time.

4) The sixth song "Number One For Me"

* S.6. St.3. L : You know you are number one for me

The lyric above was classified as the moral value of loyalty. The singer told the listener that he was still faithful to his mother, defined as a spiritual value of loyalty. His mother was the first person who taught him everything about his life. She was an individual who always forgave the error of her children so that the singer was very loyal to his mother. 
From the above results, the author discovered four moral loyalty values from four songs on Maher Zein's Thank You Allah album.

\section{Believe}

From the ten songs that the writer analyzed, the writer found five songs that consist of moral value about believe there were: Insya Allah, the chosen one, forgive me, open your eyes and love will prevail.

1) The second song "Insya Allah"

* S.2. St.1 B : Don't despair and never lose hope, cause Allah is always by your side

The lyric above was classified as the moral value of believe. The singer told to the listener that Allah did not like people who were in despair and helpless, because there would be a way out of everything that happened in life.

* S.2. St.3. B : You are the only one that showed me the way

The lyric above was classified as the moral value of believe. The singer told the listener that Allah always led us to the right way and the singer taught the listener to be a humble person in every situation.

2) The third song "The Chosen One"

* S.3. St.6. B : I pray to be close to you on that day and see you smile when you me

The lyric above was classified as the moral value of belive. The singer believed that Allah would bless him to get closer to Muhammad S.A.W.

3) The seventh song "Forgive Me"

* S.6. St.1 B : And that you have promised to always be there when I call upon you

The lyric above was classified as the moral value of believe. God has a modest characteristic. God always forgives the one who wants to return to his way. He always be there around people who needs Him.

4) The eight song "Open Your Eyes"

* S.8. St.3 B : Keep us close to you until the end of time

The lyric above was classified as the moral value of believe. Through this lyric, the singer wanted to convey to the listener that everyone had to surrender to God by praying, working hard, and believing in God. So that we would get closer to Him till the end of time and hereafter.

5) The tenth song "Love Will Prevail"

* S.10. St.2 B : Love will prevail by God it will

The lyric above was classified as the moral value of believe because the singer told the listener that believe was the strength of life, as believe to God, Prophet and each other. It meant that when people believe someone they would struggle for them. There was no fear in their heart and they won't give in to protect them.

* S.10. St.3 B : By God you will never win

The lyric above was classified as the moral value of believe because the singer told that we as a hum without God we never got what we wanted in our life.

From the data above, the writer conclude that in the insya Allah, The chosen one, Forgive me, Open your eyes and Love will prevail song consist of moral value about believe.

\section{Forgiveness}

From the ten songs of Album thank you Allah by Maher Zein only one song that consists of moral value of forgiveness. In the seventh song with the title forgive me.

1) The seventh song "Forgive Me"

* S.7. St.1. F : I know Allah you are the most forgiving 
The lyric above was classified as the moral value of forgiveness. The singer told the listener that God always forgive the one who wants to return to His way. He always around the people who needs him.

\subsection{1 f. Togetherness}

In this session, from ten songs the writer found three lyrics contained moral value of togetherness in the song fourth song entitled freedom.

1) The fourth song "Freedom"

* S.4. St.1 T : Gathered here with family, my neighbors and my friends standing firm together against oppression holding hands.

The lyric above was classified as the moral value of togetherness because the singer told that they were together in unity to face the oppression in their country to get the freedom.

* S.4. St.2 T : And we are here together calling you for freedom

The lyric above was classified as the moral value of togetherness. In the lyric the singer told that they were together for getting freedom and to become unity so they have strength to fight the oppression.

* S.4. St.3 T : Standing together holding hands and unity

The lyric above was classified as the moral value of togetherness. They invited people to encourage them to fight against all oppression.

\section{Honesty}

Honesty refers to a moral character facet which connotes good and noble qualities such as honesty, truthfulness, and simplicity, including the absence of lying, stealing, and thief, including simplicity of conduct. In addition, integrity implies being trustworthy, loyal, equitable and frank (Dafl : 2005).

According to Stanford encyclopedia of philosophy, an honest individual is someone who is honest and often discourages the dishonesty of others in their relationships with others. In all aspects of one's life, it includes honesty and the desire to be true to oneself and one's place in the world in all circumstances. In our lives, it is very simple. Honesty to ourselves or to others may be practiced.

From the ten songs that the writer analyzed, the writer found one song that contained moral value of honesty in the song entitled the chosen one, lets see the explanation below.

1) The third song "The Chosen One"

* S.3. St.3 H : Truthful in every word you say Muhammad ya Rasul Allah

The lyric above was classified as the moral value of honesty because the singer told Moeslim people to really appreciate and love prophet Muhammad because he never arrogant to anyone and always kind to the umat.

\section{Bravery}

Bravery in this context is a situation or culture that changes in a way that is supposed to better the lives of people, but it is also a source of additional issues (Hornby : 2004). It involves suffer, danger or pain.

From the ten songs that the writer analyzed there are three lyrics in one song that contained moral value of bravery. Let see the explanation below.

1) Ten tenth song "Love Will Prevail"

* S.10. St.1 B : There's no fear in my heart got nothing left to lose

The lyric above was classified as the moral value of bravery because the singer told that there was no fear in their heart, he believed that love would prevail by God's will.

\section{* S.10. St.2 B : I refuse to fail}

The lyric above was classified as the moral value of bravey. In the lyric the singer told that he always support Syrian population who were oppressed by rules. The singer wanted to show the Syrian's struggles that they would never give up to fights the truth in God's way.

* S.10. St.4 B : Cause with hardship comes ease 
The lyric above was classified as the moral value of bravery because the singer told that with the hardship and belief in God, every difficult situation would become an ease.

\section{Courage}

From the tent songs that the writer analyzed, the writer found three songs that contained moral value of courage in the song thank you Allah, for the rest of my life and love will prevail.

1) The first song "Thank You Allah"

* S.1. St.1 C : I walked everyday, further and further from you. Allah, you brought me home

The lyric above was classified as the moral value of courage because the singer told that he had given a way out by Allah who All-merciful. He described that Allah always love him and closes with him, even though he is far from God.

2) The fifth song "For The Rest Of My Life"

* S.5. St.2 C : Now and forever I'll be there for you

The lyric above was classified as the moral value of courage. In the lyric above the singer told the listener that the singer would love his wife forever and always be there for his wife.

\section{* S.5 St.3 C : And I have no doubt}

The lyric above was classified as the moral value of courage because the singer told the listener that he had no doubt to his wife.

3) The tents song "Love Will Prevail"

* S.10. St.1 : Oh I swear I won't give in

The lyric above was classified as the moral value of courage. The singer told the listener that he had a courage because he would not give in to fight.

\section{Struggle}

Struggle refers to the challenging movement or advancement or, in other words, it can be meant to survive from the challenge, mission or undertaking with the strenuous effort to survive.

There are two songs from the ten songs examined by the author that contained the moral meaning of struggle in the third and ninth song entitled the chosen one and so soon.

1) The third song "The Chosen One"

\section{* S.3. St.1 S : You came to teach us how to live}

The lyric above was classified as the moral value of struggle because the singer wanted to share the struggle of Prophet Muhammad S.A.W when people get lost. The Prophet comes as the messenger of God to teach people and lead them to the right way.

2) The ninth song "So Soon"

* S.9. St.2 S : I've got to stop the tears, keep my fight and be strong

The lyric above was classified as the moral value of struggle because the singer tried to keep the tears and keep strong.

* S.9. St.2 S : I'll try to take it all, even though it is so hard

The lyric above was classified as the moral value of struggle. In the lyric the singer always try to be strong when his father and mother passed away. He felt lonely but he had to face everything even though it was very difficult for him. From the data above, the writer found two song lyrics contained the moral value of struggle.

\section{The Theoretical Implication for English Language Teaching}

In teaching, strategy and approach are very critical since both will influence teaching methods that will impact the teaching learning process and fulfill the learning goals. In order to get an affective teaching learning 
process, teachers may use one form of approach and method or several of them together or combine them. In applying the right, effective method and methodology to their classroom, teachers need to be wise. The use of approaches and strategies depends on the students' needs and the classroom situation.

Students learn by doing where the learning takes place because, from their own experience when reading the text, students are able to interpret text on film and create meaning based on their interpretive view and critical thinking. The use of songs as a way of teaching English literature also offers another value.

Both implied or explicit, song reflecting life experiences mainly contained moral meaning, as literature represents the experience of human life and seeks to build and enrich society by teaching it through English literature. When listening to music, learners can discover moral values. In order to enrich their knowledge and personal development, the student should take the moral meaning out of what they have learned.

A teacher must have extrinsic experience of teaching literature at junior high school. So the teacher can clearly teach it, and the students can get the lesson correct. We should make a lesson plan to teach English as an instructor. A lesson plan is what the teacher uses before he or she teaches the students' materials. By using the lesson plan, the instructor can teach English easily.

\section{Discussion}

Nowadays, song is not only showing us about violence and entertainment but also about moral value or moral message. In order to find out something useful for education, it can be a teaching media.

Song, especially the ten songs in Maher Zein's Thank You Allah album, can be a means of moral teaching for the students because the songs have high motivation and educational values to teach the students how they should be, how they do in their daily life, how they entertain, moral values, and so on. Through this album, it is appropriate to express a moral value.

By using psychological approach through three data sources in triangulation, the writer examined the moral values and performed qualitative analysis technique. In the album Thank You Allah by Maher Zein, the writer found ten moral values: love and affection, believing, luckily, forgiveness, fidelity, solidarity, integrity, bravery, courage and struggle.

In English language teaching, the song of Maher Zein is suitable as a means of instruction. Before playing, the instructor or lecturer should provide orientation first for the learning process using this song. So, the students have provision for the song being studied. The teacher or instructor should also always accompany the students to learn.

\section{Conclusions}

It can be concluded that the lyric of Maher Zein is an inspring song after examining moral meaning in the Album Thank You Allah by Maher Zein. It problems with certain aspects of human life true experience. The album includes ten moral values: love and affection, trust, thankfully, forgiveness, allegiance, togetherness, integrity, bravery, courage and struggle. There are ten moral values.

The theoretical consequence of language teaching is that students will ideally learn and implement certain strong moral values in their everyday lives. Therefore, they not only get entertainment but also moral messages that are used in the songs through listening to the music.

\section{References}

Brumfit, C.J. (1981). English for International Communication. London: Pergamon Press.

Djauhari, Imam D. (I996). Mastery on English Grammar. Surabaya: Indah.

Lucantony, Peter. (2006). Teaching and Assessing Skill in English as a Second Language. United Kingdom: Cambridge University Press.

Simaibang, B. (2017). English Language Teaching in Foreign Situation. Second Edition Citra Books: Palembang. Bertens,K. (1997). Etika. PT Gramedia Pustaka Utama:Jakarta. 
Nassaji, H. (2016). Qualitative and descriptive research: Data type versus data analysis. Canada: University of Victoria

Arikunto, S. (1990). Manajemen Penelitian. Jakarta: PT Rineka Cipta.

Webster. (1981). Third New International Dictionary. USA.: Meriam Webster Inc. 